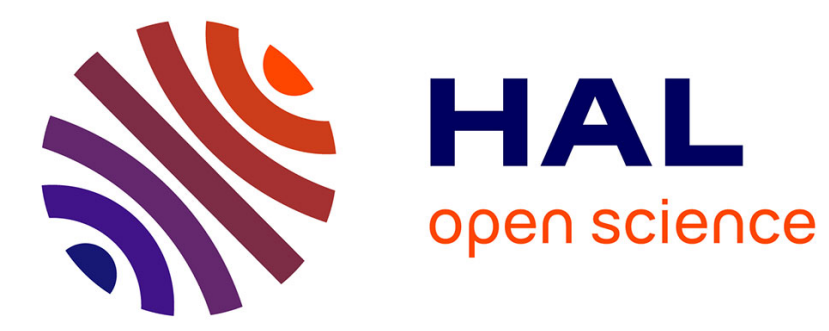

\title{
Cool-SPS: an opportunity for low temperature sintering of thermodynamically fragile materials
}

Thomas Hérisson de Beauvoir, Anna Sangregorio, Iñaki Cornu, Catherine Elissalde, Michaël Josse

\section{- To cite this version:}

Thomas Hérisson de Beauvoir, Anna Sangregorio, Iñaki Cornu, Catherine Elissalde, Michaël Josse. Cool-SPS: an opportunity for low temperature sintering of thermodynamically fragile materials. Journal of Materials Chemistry C, 2018, 6 (9), pp.2229-2233. 10.1039/C7TC05640K . hal-01766414

\section{HAL Id: hal-01766414 https://hal.science/hal-01766414}

Submitted on 13 Apr 2018

HAL is a multi-disciplinary open access archive for the deposit and dissemination of scientific research documents, whether they are published or not. The documents may come from teaching and research institutions in France or abroad, or from public or private research centers.
L'archive ouverte pluridisciplinaire HAL, est destinée au dépôt et à la diffusion de documents scientifiques de niveau recherche, publiés ou non, émanant des établissements d'enseignement et de recherche français ou étrangers, des laboratoires publics ou privés. 


\title{
Cool-SPS an opportunity for low temperature sintering of fragile materials
}

\author{
Thomas Herisson de Beauvoir ${ }^{a, b}$, Anna Sangregorio ${ }^{a, b}$, Iñaki Cornu ${ }^{a, b}$, Catherine Elissalde ${ }^{a, b}$, \\ Michael Josse $e^{a, b, c}$
}

Sintering has been achieved by Spark Plasma Sintering at low temperatures $\left(<400^{\circ} \mathrm{C}\right)$ and relatively high pressures (300 to $600 \mathrm{MPa}$ ) for various thermodynamically fragile compounds (carbonates, sulfate, and phosphate) decomposing between 220 and $780^{\circ} \mathrm{C}$. Our work is a proof of concept of the possibility to sinter efficiently ( $>90 \%$ of theoretical density) fragile materials, and also highlights the extra stability of several materials, sintered above their decomposition temperature. Through various examples, the potential of Cool-SPS for fast and efficient sintering of fragile materials, which are impossible to sinter by conventional sintering techniques, is depicted.

Sintering of ceramics represents an important stake for materials industry. It has been performed for ages, and still is, to obtain dense materials from powders. Sintering is usually achieved through high temperature treatment (typically $\mathrm{T} \geq$ $1000{ }^{\circ} \mathrm{C}$ ), the driving force being surface free energy reduction ${ }^{1}$ These last decades, a thorough interest has been focused on reducing the sintering temperature ${ }^{2-4}$, which not only allows energy- and cost-efficient processing, but also gives access to new physical properties, for example through nanostructured ceramics $^{4-7}$. Development of new sintering techniques ${ }^{8}$ followed, among which pressure assisted sintering such as Hot Pressing $(\mathrm{HP})^{9}$ or Hot Isostatic Pressing (HIP) $)^{10}$, microwave sintering ${ }^{11}$, or field assisted sintering techniques ${ }^{12,13}$. Among these, Spark Plasma Sintering (SPS) is an excellent candidate for the reduction of both sintering temperature and duration ${ }^{14-16}$, while Microwave sintering (MS) has shown interesting results, with high sintering kinetics ${ }^{11}$. At the same time liquid sintering techniques have been developed ${ }^{17-19}$, paving the way to Hydrothermal Hot Pressing (HHP) ${ }^{20}$, which operates at very low temperatures $\left(<350{ }^{\circ} \mathrm{C}\right)^{21-24}$. Very recently, the development of the Cold Sintering Process (CSP) lead to a high densification level while operating from room temperature to $200{ }^{\circ} \mathrm{C}^{25-28}$. Despite these significant developments, some challenges remain, in particular to densify functional materials. In the present work, we explore the densification of materials with limited thermodynamic stability (due to low temperature decomposition, phase transition...), that we refer to as "fragile materials". To this end, we use SPS at relatively high pressure (from 300 to $600 \mathrm{MPa}$ ) and low temperature (typically below $400{ }^{\circ} \mathrm{C}$ ), which we will refer to as "Cool-SPS" in the following, to

\footnotetext{
a. CNRS, ICMCB, UPR9048, Pessac, 33600, France

b. Université de Bordeaux, ICMCB, UPR9048, Pessac, 33600, France.

c. To whom correspondence should be addressed michael.josse@icmcb.cnrs.fr

+ Footnotes relating to the title and/or authors should appear here.

Electronic Supplementary Information (ESI) available: [details of any supplementary information available should be included here]. See DOI: 10.1039/x0xx00000x
}

obtain highly dense functional ceramics. Four materials have been selected for their potential (multi)ferroic or magnetoelectric properties. $\mathrm{MnSO}_{4}$, displays a complex magnetic order that could induce a ferroelectric polarization ${ }^{29}$ and decomposes in air at $780{ }^{\circ} \mathrm{C} . \mathrm{K}_{2} \mathrm{Cu}\left(\mathrm{CO}_{3}\right)_{2}$ and $\mathrm{Na}_{2} \mathrm{Cu}\left(\mathrm{CO}_{3}\right)_{2}$ decompose in air at 270 and $220^{\circ} \mathrm{C}$ respectively, the former being a non-centrosymmetric ferromagnet ${ }^{30}$ (thus a potential multiferroic), the latter an antiferromagnet ${ }^{31} . \mathrm{NH}_{4} \mathrm{FeP}_{2} \mathrm{O}_{7}$ decomposes in air at $170{ }^{\circ} \mathrm{C}$, and is isostructural to $\mathrm{KCrP}_{2} \mathrm{O}_{7}$, a potential magnetoelectric material ${ }^{32}$. In this communication, the characterization of the precursor powders will be detailed, as well as densification conditions, and structural and microstructural properties of the ceramics. Finally, the potential of Cool-SPS will be discussed, particularly as a prospection tool to explore the properties of fragile materials that could not be obtained in ceramic form otherwise.

\section{Results and discussion}

\section{Powder characteristics}

Powders used for sintering have been characterized by XRD in order to confirm the presence of the target phases, or their hydrated precursor in the case of $\mathrm{MnSO}_{4}$ and $\mathrm{Na}_{2} \mathrm{Cu}\left(\mathrm{CO}_{3}\right)_{2}$, and the absence of remaining impurities. TGA measurements were also performed on these powders to determine their decomposition temperature in air, and their dehydration temperature when relevant. Figure S1 displays results of both TGA and XRD on each precursor, and table S2 gathers the cell parameters refined from XRD data. XRD profile refinement for the $\mathrm{MnSO}_{4} \cdot \mathrm{H}_{2} \mathrm{O}$ precursor confirmed its phase purity, with cell parameters in excellent agreement with literature data ${ }^{34}$ (table S2). TGA confirmed the $\mathrm{MnSO}_{4} \cdot \mathrm{H}_{2} \mathrm{O}$ composition of the precursor and the stability of $\mathrm{MnSO}_{4}$ beyond its sintering temperature of $400^{\circ} \mathrm{C}$. XRD profile refinement of $\mathrm{Na}_{2} \mathrm{Cu}\left(\mathrm{CO}_{3}\right)_{2} \cdot 3 \mathrm{H}_{2} \mathrm{O}$ confirmed its phase purity, with refined cell parameters consistent with the literature ${ }^{36}$. TGA measurement is consistent with $3 \mathrm{H}_{2} \mathrm{O}$ molecules per $\mathrm{Na}_{2} \mathrm{Cu}\left(\mathrm{CO}_{3}\right)_{2}$ formula unit. It should be noted that a complex liquid route is required to obtain the anhydrous form, as described in previous studies 32,37-39 and established by Deville ${ }^{40}$. Decomposition temperature of $\mathrm{Na}_{2} \mathrm{Cu}\left(\mathrm{CO}_{3}\right)_{2}$ under air was determined as $220^{\circ} \mathrm{C}$. XRD pattern refinement for $\mathrm{K}_{2} \mathrm{Cu}\left(\mathrm{CO}_{3}\right)_{2}$ revealed the absence of any secondary phase, with lattice parameters corresponding to those refined on single crystal ${ }^{41}$. TGA measurement on $\mathrm{K}_{2} \mathrm{Cu}\left(\mathrm{CO}_{3}\right)_{2}$ revealed a decomposition 
temperature of $270{ }^{\circ} \mathrm{C}$ under air. XRD pattern of $\mathrm{NH}_{4} \mathrm{FeP}_{2} \mathrm{O}_{7}$ revealed residual $\mathrm{Fe}_{2} \mathrm{O}_{3}$ that could not be avoided by optimizing the synthesis process. Nonetheless, $\mathrm{NH}_{4} \mathrm{FeP}_{2} \mathrm{O}_{7}$ lattice parameters are in good agreement with the literature ${ }^{42}$. TGA measurement revealed a decomposition temperature of $170^{\circ} \mathrm{C}$ in air. However, this material being synthesized under vacuum at $210^{\circ} \mathrm{C}$ (and decomposing at $220^{\circ} \mathrm{C}$ in such conditions), and Cool-SPS being also performed under vacuum, the decomposition temperature of $220^{\circ} \mathrm{C}$ was retained.

\section{Densification}

Dwell time is set to 5 minutes for all the samples and the sintering is performed under primary vacuum ( $-10 \mathrm{~Pa})$. Densification by Spark Plasma Sintering (SYNTEX, Dr. Sinter 515S apparatus) has been performed with different conditions for each composition, which are reported, with the corresponding relative densities of the obtained ceramics, in Table 1 . For the four compositions, dense and cohesive pellets have been obtained with apparent good mechanical strength, as the pellets could be manipulated and polished without disintegrating, as would be the case for crude or poorly sintered pellets. XRD confirmed phase purity, for all the obtained pellets (Figure S3), and the lattice parameters obtained from these refinements (Table S2) are in agreement with those reported in the literature for all the target compositions. This demonstrates the good preservation of the materials structure during sintering when starting from identical powders, and confirms the successful in situ dehydration of the precursors in the cases of $\mathrm{MnSO}_{4}$ and $\mathrm{Na}_{2} \mathrm{Cu}\left(\mathrm{CO}_{3}\right)_{2}$, which cell parameters are consistent with those available in the literature ${ }^{32,43}$. As can be seen from Table 1, relative densities of $95 \%$ and beyond were obtained for all materials. This is a remarkable result considering the densifications were performed at temperatures ranging between 300 and $400{ }^{\circ} \mathrm{C}$. Microstructures were investigated by Scanning Electron Microscopy (SEM). Images of fractured pellets are displayed on Figure 1 for the four investigated materials. In every case, we observe very dense microstructures with no visible porosity. These observations are in good agreement with the measured relative densities and confirm the high efficiency of Spark Plasma Sintering, even at temperatures as low as $200{ }^{\circ} \mathrm{C}\left(\mathrm{NH}_{4} \mathrm{FeP}_{2} \mathrm{O}_{7}, 95 \%\right)$.

Table 1: Decomposition temperature, sintering conditions and relative densities obtained for the target compositions. Relative density ranges are respective to the corresponding sintering temperatures ranges

\begin{tabular}{ccccc}
\hline Material & $\begin{array}{c}\text { Decompos. } \\
\text { temp. }\left({ }^{\circ} \mathrm{C}\right) \\
\text { (air) }\end{array}$ & $\begin{array}{c}\text { Sintering } \\
\text { temp. }\left({ }^{\circ} \mathrm{C}\right) \\
\text { (vac.) }\end{array}$ & $\begin{array}{c}\text { Sintering } \\
\text { pressure } \\
\text { (MPa) }\end{array}$ & $\begin{array}{c}\text { Relative } \\
\text { density } \\
\text { (\%) }\end{array}$ \\
\hline $\mathrm{MnSO}_{4}{ }^{*}$ & 780 & 400 & 400 & 96 \\
\hline $\mathrm{K}_{\mathbf{2}} \mathrm{Cu}\left(\mathrm{CO}_{3}\right)_{2}$ & 270 & 300 to 350 & 600 & 94 to 95 \\
\hline $\mathrm{Na}_{2} \mathrm{Cu}\left(\mathrm{CO}_{3}\right)_{2}{ }^{*}$ & 220 & 250 to 300 & 600 & 97 to 98 \\
\hline $\mathbf{N H}_{4} \mathrm{FeP}_{2} \mathbf{O}_{7}$ & $\begin{array}{c}170 \\
220 \text { (vac.) }\end{array}$ & 200 to 300 & 300 & 95 to 98 \\
\hline
\end{tabular}

$\left({ }^{*}\right)$ ceramics obtained by sintering a hydrated precursor

\section{In situ dehydration}

For both hydrated precursors, in situ dehydration can be followed during SPS experiments through chamber pressure monitoring. When a gas release occurs, the chamber pressure increases, then decreases at the end of the release, indicating the corresponding dehydration temperature range. On Figure $\mathrm{S} 4$ is plotted the chamber pressure during Cool-SPS treatment of $\mathrm{MnSO}_{4} \cdot \mathrm{H}_{2} \mathrm{O}$ and $\mathrm{Na}_{2} \mathrm{Cu}\left(\mathrm{CO}_{3}\right)_{2} \cdot 3 \mathrm{H}_{2} \mathrm{O}$, which is further compared to DTG under air. In the case of $\mathrm{MnSO}_{4} \cdot \mathrm{H}_{2} \mathrm{O}$ a temperature shift is observed for the dehydration, from $110^{\circ} \mathrm{C}$ (DTG) to $250^{\circ} \mathrm{C}$ (Cool-SPS), which may be due to a stabilization of the hydrated form under pressure. In the case of $\mathrm{Na}_{2} \mathrm{Cu}\left(\mathrm{CO}_{3}\right)_{2} \cdot 3 \mathrm{H}_{2} \mathrm{O}$, DTG measurement shows a total dehydration at $160^{\circ} \mathrm{C}$, while SPS chamber pressure shows an important water release from 70 to $130{ }^{\circ} \mathrm{C}$. Thus, dehydration appears to be shifted towards lower temperatures by the application of a pressure of $600 \mathrm{MPa}$. It is also worth mentioning the absence of gas release corresponding to decomposition up to $300{ }^{\circ} \mathrm{C}$, although such a decomposition is observed above $220^{\circ} \mathrm{C}$ in air. Remarkably, $\mathrm{Na}_{2} \mathrm{Cu}\left(\mathrm{CO}_{3}\right)_{2}$ was obtained in situ during Cool-SPS processing, while attempts to prepare it conventionally (heating in a furnace between dehydration and decomposition temperature) failed.

\section{Increased stability in Cool-SPS conditions}

Regarding the sintering temperatures presented in Table 1, another striking feature is that they are located beyond the decomposition temperatures under air (and also under vacuum for $\mathrm{NH}_{4} \mathrm{FeP}_{2} \mathrm{O}_{7}$ ) for three of the four investigated materials. Figure 2 summarizes sintering and decomposition temperatures for the various tested materials, along with the relative densities of the elaborated ceramics. On the one hand, it can be seen that $\mathrm{K}_{2} \mathrm{Cu}\left(\mathrm{CO}_{3}\right)_{2}$ has been sintered $80{ }^{\circ} \mathrm{C}$ beyond its decomposition temperature in air. $\mathrm{NH}_{4} \mathrm{FeP}_{2} \mathrm{O}_{7}$ has been sintered at temperatures ranging from 200 to $300{ }^{\circ} \mathrm{C}$, but has a decomposition temperature of $220^{\circ} \mathrm{C}$ under vacuum, and of $170{ }^{\circ} \mathrm{C}$ in air. Finally, $\mathrm{Na}_{2} \mathrm{Cu}\left(\mathrm{CO}_{3}\right)_{2}$ has been sintered from its hydrated form $\mathrm{Na}_{2} \mathrm{Cu}\left(\mathrm{CO}_{3}\right)_{2} \cdot 3 \mathrm{H}_{2} \mathrm{O}$ up to $80^{\circ} \mathrm{C}$ beyond its decomposition temperature of $220^{\circ} \mathrm{C}$ in air. Thus, there is a stabilization of these phases in Cool-SPS conditions, which increases its potential. On the other hand, the sintering of $\mathrm{MnSO}_{4}$ did not require to approach its decomposition, as an efficient sintering was obtained at $400^{\circ} \mathrm{C}$, i.e. $380^{\circ} \mathrm{C}$ below its decomposition temperature. 

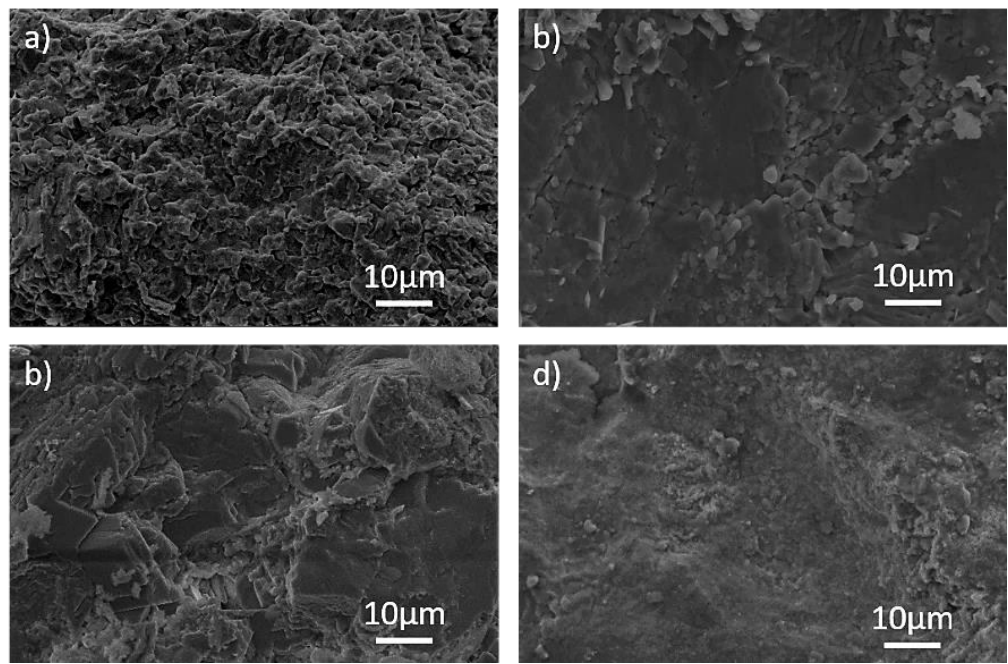

Figure 1: SEM images obtained on fractured pellets for (a) $\mathrm{MnSO}_{4}$, (b) $\mathrm{K}_{2} \mathrm{Cu}\left(\mathrm{CO}_{3}\right)_{2}$, (c) $\mathrm{Na}_{2} \mathrm{Cu}\left(\mathrm{CO}_{3}\right)_{2}$ and $\left(\right.$ d) $\mathrm{NH}_{4} \mathrm{FeP}_{2} \mathrm{O}_{7}$

\section{Cool-SPS: extending the field of ceramic science}

The results presented in this communication highlight the efficiency of Cool-SPS, and its contribution to widening the opportunities associated with efficient sintering at low temperature. To begin with, Cool-SPS is demonstrated as a powerful technique to quickly densify fragile materials at temperatures below $400^{\circ} \mathrm{C}$, and even as low as $200{ }^{\circ} \mathrm{C}$. Moreover, Cool-SPS also allowed for the stabilization of three of the four investigated materials beyond their decomposition temperatures, further extending the range of experimental conditions and raising the chances of success of the sintering. This opens a large window for prospection since Cool-SPS can be used to obtain dense ceramics from powders with limited thermodynamical stability. Thus, it becomes possible to explore bulk properties of such materials (electric and dielectric properties in the present approach, but possibly many others), and to develop prospective research doing so. Furthermore, the specific case of $\mathrm{Na}_{2} \mathrm{Cu}\left(\mathrm{CO}_{3}\right)_{2}$, obtained through in situ dehydration, is a proof that Cool-SPS can be used to isolate a specific phase that may not be obtained through conventional routes, or even to synthesize new materials. Finally, if in the case of $\mathrm{MnSO} 4$ sintering is performed below the decomposition temperature $\left(400^{\circ} \mathrm{C}\right.$ vs $780^{\circ} \mathrm{C}$, resp.), this example shows that an effective sintering can be obtained at very low temperature, and raise the question whether the SPS processing temperature of more traditional functional materials (oxides for example) can be further lowered. Let's also remind that all the sintered pellets were obtained after a 5 minutes dwell and a sintering treatment lasting around 30 minutes overall.

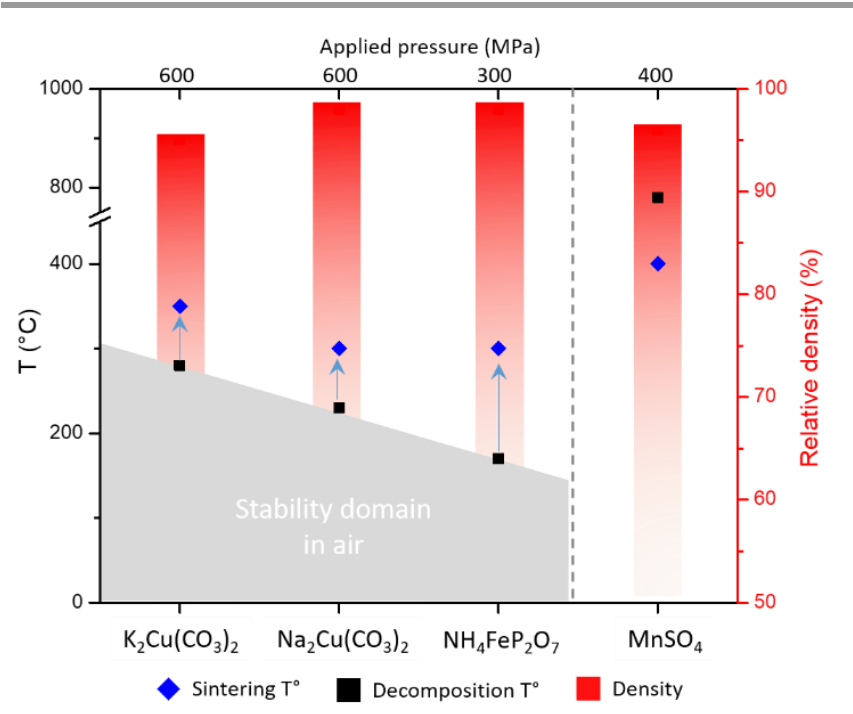

Figure 2: Decomposition temperatures, Cool-SPS conditions (temperature and pressures) and relative densities of obtained ceramics for all the fragile materials. Arrows represent the gain in stability in Cool-SPS conditions and grey zone represents the stability domain of precursors.

\section{Conclusions}

Cool-SPS, relying on high pressure (300 to $600 \mathrm{MPa}$ ) and low temperature $\left(\leq 400^{\circ} \mathrm{C}\right)$ has allowed:

l) The preparation of phase pure and dense ceramics (95\%$98 \%$ ) of thermodynamically fragile materials

ii) The sintering of fragile materials above their decomposition temperature increasing significantly the thermodynamic window for densification

iii) The in situ preparation of fragile materials, from hydrated precursors

iv) The in situ preparation of a fragile material that cannot be obtained quantitatively by other means 
v) The rapid and efficient sintering of materials below $400^{\circ} \mathrm{C}$, making Cool-SPS a promising cost- and energy effective densification method with limited environmental footprint. Indeed, combining very low temperature, extremely short sintering time and phase stabilization beyond the usual stability range not only offers wide possibilities both for prospective search of new functional materials, but also allows for the development of energy-efficient elaboration routes for functional ceramics, possibly reducing the associated environmental footprint. Thus, Cool-SPS is a promising technique that opens wide territories for exploration, be it fragile ceramics, low temperature densification or nonconventional synthesis of new materials, and that deserves to be further developed.

The present communication provides a proof of concept of Cool-SPS as a fast, potentially cost-effective, energy-effective and environmentally friendly technique, that can easily be scaled up. Cool-SPS open new opportunities in terms of ceramic preparation, composition and properties, allowing for further development of exploratory research on low-temperature sintering mechanisms, as well as prospection for new fragile functional materials.

\section{Conflicts of interest}

"There are no conflicts to declare".

\section{References}

R. M. German, Sintering theory and practice, Wiley, Wiley: New., 1996. H. Yu, J. Liu, W. Zhang and S. Zhang, J. Mater. Sci. Mater. Electron., 2015, 26, 9414-9423. M. T. Sebastian, H. Wang and H. Jantunen, Curr. Opin. Solid State Mater. Sci., 2016, 20, 151-170. H. T. Kim and Y. H. Han, Ceram. Int., 2004, 30, 1719-1723. I.-W. Chen and X. Wang, Nature, 2000, 404, 168-171. A. Polotai, K. Breece, E. Dickey, C. Randall and A. Ragulya, J. Am. Ceram. Soc., 2005, 88, 3008-3012. C. Bousquet, C. Elissalde, C. Aymonier, M. Maglione, F. Cansell and J. M. Heintz, J. Eur. Ceram. Soc., 2008, 28, 223228. R. H. R. C. and K. Van Benthem, A. Lakshmanan, W. E. Lee and Suk-Joong L.Kang, Sintering of ceramics - new emerging techniques, 2012. R. L. Coble and J. S. Ellis, J. Am. Ceram. Soc., 1963, 46, 438441. M. H. Bocanegra-Bernal, J. Mater. Sci., 2004, 39, 63996420.

11 D. Agrawal, Trans. Indian Ceram. Soc., 2006, 65, 129-144.

12 C. E. J. Dancer, Mater. Res. Express, 2016, 3, 102001.

13 Z. A. Munir, U. Anselmi-Tamburini and M. Ohyanagi, J. Mater. Sci., 2006, 41, 763-777.

14 U. Anselmi-Tamburini, J. E. Garay and Z. A. Munir, Scr. Mater., 2006, 54, 823-828.
R. Chaim, M. Levin, a. Shlayer and C. Estournes, Adv. Appl. Ceram., 2008, 107, 159-169.

O. Guillon, J. Gonzalez-Julian, B. Dargatz, T. Kessel, G. Schierning, J. Rathel and M. Herrmann, Adv. Eng. Mater., 2014, 16, 830-849.

R. M. German, P. Suri and S. J. Park, J. Mater. Sci., 2009, 44, 1-39.

18 R. M. German, S. Farooq and C. M. Kipphut, Mater. Sci. Eng., 1988, 105-106, 215-224.

D. L. Corker, R. W. Whatmore, E. Ringgaard and W. W. Wolny, J. Eur. Ceram. Soc., 2000, 20, 2039-2045. N. Yamasaki, K. Yanagisawa, M. Nishioka and S. Kanahara, J. Mater. Sci. Lett., 1986, 5, 355-356.

K. Yanagisawa, M. Nishioka, K. loku and N. Yamasaki, J. Mater. Sci. Lett., 1993, 12, 1073-1075.

K. Yanagisawa, K. loku and N. Yamasaki, J. Am. Ceram. Soc., 1997, 80, 1303-1306. N. Yamasaki, T. Weiping and K. Jiajun, J. Mater. Sci. Lett., 1992, 11, 934-936.

N. Yamasaki, T. Kai, M. Nishioka, K. Yanagisawa and K. loku, J. Mater. Sci. Lett., 1990, 9, 1150-1151. J. Guo, S. S. Berbano, H. Guo, A. L. Baker, M. T. Lanagan and C. A. Randall, Adv. Funct. Mater., 2016, 26, 1-7. J. Guo, H. Guo, A. L. Baker, M. T. Lanagan, E. R. Kupp, G. L. Messing and C. A. Randall, Angew. Chemie Commun., 2016, 55, 1-6. H. Guo, A. Baker, J. Guo and C. A. Randall, J. Am. Ceram. Soc., 2016, 19, 1-19. H. Guo, A. Baker, J. Guo and C. A. Randall, ACS Nano, 2016, 10(11), 10606-10614. G. Will, B. C. Frazer, G. Shirane, D. E. Cox and P. J. Brown, Phys. Rev., 1965, 140, 2139-2142. A. Farrand, A. Gregson, B. Skelton and A. White, Aust. J. Chem., 1980, 33, 431-434. A. K. Gregson and N. T. Moxon, Inorg. Chem., 1981, 20, 7881.

S. Gentil, D. Andreica, M. Lujan, J. Rivera, F. Kubel and H. Schmid, Ferroelectrics, 1997, 204, 35-44. 